\title{
PENERAPAN POLA PEMBELAJARAN BERBASIS MULTIMEDIA TERHADAP PENINGKATAN HASIL BELAJAR SISWA SMK PADA MATERI KATUP PNEUMATIK
}

\author{
Muhamad Ramdan ${ }^{1}$ Ida Hamidah ${ }^{2}$, Purnawan ${ }^{3}$ \\ Departemen Pendidikan Teknik Mesin \\ Universitas Pendidikan Indonesia \\ Jl. Dr. Setiabudhi No. 207 Bandung 40154 \\ muhamad.r@student.upi.edu
}

\begin{abstract}
ABSTRAK
Penelitian ini bertujuan mendapatkan gambaran perbedaan peningkatan hasil belajar antara siswa yang menggunakan pola pembelajaran multimedia presentasi dengan multimedia interaktif. Penelitian ini menggunakan metode penelitian quasi experimental dengan desain penelitian nonequivalent control group design. Hasil penelitian menunjukkan ada perbedaan peningkatan hasil belajar siswa antara kelompok yang menggunakan multimedia presentasi dan multimedia interaktif. Nilai rata-rata $\mathrm{N}$-Gain siswa yang menggunakan multimedia presentasi berkategori sedang dan yang menggunakan multimedia interaktif berkategori rendah. Disimpulkan bahwa penggunaan multimedia presentasi berpengaruh lebih baik pada peningkatan hasil belajar siswa dibandingkan penggunaan multimedia interaktif pada materi katup pneumatik.
\end{abstract}

Kata kunci: pneumatik, multimedia, presentasi, interaktif, pembelajaran

\begin{abstract}
This study aims to get information about the differences of students' learning outcomes between the students who learn by using multimedia presentation and the students who learn by using interactive multimedia. This quantitative research used quasi-experimental method with nonequivalent control group design. The results of the reasearch showed that there were the differences of the improvement of the students' learning outcomes between multimedia presentation group and interactive multimedia group. The average scores of $\mathrm{N}$-Gain students which used multimedia presentation were categorized as medium, while the average scores of $\mathrm{N}$-Gain students used interactive multimedia were low category. It can be concluded that the application of multimedia presentation in this research is better than interactive multimedia in improving students' learning outcomes in pneumatic valve material.
\end{abstract}

Keywords: pneumatic, multimedia, presentation, interactive, learning design

\footnotetext{
${ }^{1}$ Mahasiswa Departemen Pendidikan Teknik Mesin FPTK UPI

${ }^{2}$ Dosen Departemen Pendidikan Teknik Mesin FPTK UPI

${ }^{3}$ Dosen Departemen Pendidikan Teknik Mesin FPTK UPI
} 


\section{PENDAHULUAN}

Salah satu dampak dari perubahan Kurikulum 2013 adalah perubahan struktur mata pelajaran. Mata pelajaran aircraft hydraulic \& pneumatic system merupakan salah satu mata pelajaran baru yang ada di paket keahlian Kontruksi Rangka Pesawat Udara (KRPU) sesuai dengan penerapan Kurikulum 2013. Sesuai dengan silabus mata pelajaran aircraft hydraulic \& pneumatic system, sistem pneumatik merupakan materi baru yang harus dipelajari oleh siswa paket keahlian KRPU. Pada pelajaran ini, materi yang paling penting untuk dipahami adalah tentang katup pneumatik. Simbol-simbol katup pneumatik yang sudah distandarkan hanya berupa gambar dan kode penomoran. Untuk memahami cara kerja dari simbol-simbol tersebut diperlukan suatu media yang dapat menjelaskan prinsip kerja simbol-simbol tersebut secara realistis. Simbol-simbol pneumatik standar (DIN ISO 1219 dan 5599) tidak cukup representatif untuk mampu menjelaskan secara realistis cara kerja komponen pneumatic (Purnawan, 2006). Oleh karena itu, dalam proses pembelajaran katup pneumatik ini dibutuhkan suatu alat bantu yang variatif untuk menyampaikan materi pelajaran yaitu dengan menggunakan multimedia pembelajaran.

Multimedia sebagai alat yang dapat menciptakan presentasi yang dinamis dan interaktif yang mengombinasikan teks, grafik, animasi, audio, dan video. Multimedia is the combination of the following elements: text, color, graphics, animations, audio, and video (Munadi, 2012). Media pembelajaran berbantuan multimedia interaktif memiliki pengaruh yang positif pada peningkatan minat siswa terhadap pembelajaran sistem pneumatik dan dapat meningkatkan pemahaman siswa terhadap prinsip kerja komponen pneumatic (Hidayah \& Hasbullah, 2014). Peningkatan hasil belajar siswa di kelompok kontrol (menggunakan gambar dan menerapkan metode pembelajaran klasik) memperoleh nilai rata-rata pada kategori sedang (Purnawan, 2012). Sedangkan, peningkatan hasil belajar di kelompok eksperimen (menggunakan animasi dan menerapkan metode pembelajaran semi individu) memperoleh nilai rata-rata pada kategori sedang.

Salah satu penguatan pola pembelajaran pada Kurikulum 2013 adalah pola pembelajaran yang berpusat pada peserta didik dan penguatan pembelajaran berbasis multimedia. Pola pembelajaran adalah jenis-jenis proses penyampaian kurikulum kepada siswa baik secara langsung antara guru dan siswa, ataupun secara tidak langsung siswa dengan alat peraga pendidikan, dan lain sebagainya. (Rohani, 2004).

Multimedia presentasi merupakan metode pembelajaran yang memberikan pengaruh yang sangat besar, bukan hanya pada pengembangan kegiatan praktis dalam kegiatan pembelajaran, akan tetapi pada teori-teori yang mendasarinya. Multimedia 
interaktif merupakan program yang dirancang untuk digunakan oleh siswa secara individual/belajar mandiri. Pada pembelajaran secara interaktif, banyak panca indera yang terlibat aktif dalam pembelajaran, diantaranya penggunaan panca indra secara auditif, visual, dan kinetik. Multimedia interaktif adalah suatu multimedia yang dilengkapi dengan alat pengontrol yang dapat dioperasikan oleh pengguna, sehingga pengguna dapat memilih apa yang dikehendaki untuk proses selanjutnya (Kusantati, 2014). Contoh multimedia interaktif adalah aplikasi game dan CD interaktif.

Tujuan penelitian ini adalah mendapatkan gambaran perbedaan peningkatan hasil belajar siswa pada penggunaan multimedia yang diterapkan dalam pola pembelajaran multimedia presentasi dengan pola pembelajaran multimedia interaktif. Kedua pola pembelajaran yang diterapkan dalam penelitian ini merupakan implementasi dari penguatan pola pembelajaran yang berpusat pada peserta didik dan pola pembelajaran berbasis multimedia sesuai dengan Kurikulum 2013.

Pneumatik berarti terisi udara atau gerakan oleh udara (Direktorat Pembinaan SMK, 2014). Sistem pneumatik pada pesawat diaplikasikan untuk menggerakkan komponen-komponen dan sistem penggerak pada rem, buka tutup pintu, pelepas dan penarik roda pendaratan pesawat. Sistem kontrol pada pneumatik terdiri dari 5 bagian utama, yaitu energy supply, input elements (sensors), processing elements (processors), control elements, dan power components (actuators)" (Croser and Ebel, 2002). Komponen-komponen kontrol tersebut biasa disebut katup-katup (valves). Katup pneumatik berfungsi untuk mengatur dan mengendalikan arah aliran udara bertekanan yang akan menggerakkan aktuator.

\section{METODE PENELITIAN}

Desain eksperimen yang digunakan adalah quasi experimental. Desain penelitian yang digunakan dalam penelitian ini adalah desain penelitian non-equivalent control group design. Penelitian ini dilaksanakan di SMK Negeri 12 Bandung, dengan subjek penelitian ini adalah siswa kelas XI di jurusan KRPU tahun ajaran 2014/2015. Prosedur dalam penelitian ini dilaksanakan dalam tiga tahap, yaitu tahap persiapan, tahap pelaksanaan, dan tahap akhir penelitian. Sampel yang digunakan, yaitu kelas XI KRPU yang terdiri dari 60 orang. Sampel ini terbagi menjadi dua kelompok yaitu kelas XI KRPU 1 untuk kelompok eksperimen 1 dan kelas XI KRPU 2 untuk kelompok eksperimen 2. Jumlah siswa masingmasing kelas yang digunakan adalah 30 orang. Instrumen penelitian ini berupa tes tertulis 
berbentuk pilihan ganda berjumlah 40 soal, dengan 5 alternatif jawaban yang sudah divalidasi sebelumnya. Analisis data yang digunakan pada penelitian ini adalah teknik analisis statistik. Teknik analisis data yang dilakukan adalah pengujian homogenitas pada hasil pretest, pengujian normalitas pada data posttest, dan pengujian hipotesis.

\section{HASIL PENELITIAN}

Data peningkatan hasil belajar siswa merupakan parameter penelitian yang diperoleh dari hasil pretest dan posttest. Deskripsi data skor hasil belajar pada kelas eksperimen 1 dan eksperimen 2 ditunjukkan pada Tabel 1.

Tabel 1. Data hasil belajar siswa pada kelas eksperimen

\begin{tabular}{ccccc}
\hline \multirow{2}{*}{ Data } & \multicolumn{2}{c}{ Kelas Eksperimen 1 } & \multicolumn{2}{c}{ Kelas Eksperimen 2 } \\
\cline { 2 - 5 } & Pretest & Posttest & Pretest & Posttest \\
\hline Skor tertinggi & 37,50 & 85 & 42,50 & 70 \\
\hline Skor terendah & 17,50 & 25 & 7,50 & 12,50 \\
\hline Rata-rata & 26,34 & 56,70 & 19,42 & 37,21 \\
\hline Standar deviasi & 5,114 & 13,895 & 7,85 & 18,44 \\
\hline Varians & 26,149 & 193,08 & 61,65 & 340,16 \\
\hline
\end{tabular}

Data hasil penelitian diperoleh data kategori $N$-Gain pada kelas eksperimen 1 dan eksperimen 2 ditunjukkan pada Tabel 2.

Tabel 2. Data indeks hasil belajar siswa pada kelas eksperimen

\begin{tabular}{ccccc}
\hline Kelas & Rata-rata $N$-Gain & Kategori & Frekuensi & Presentase \\
\hline \multirow{2}{*}{$\begin{array}{c}\text { Eksperimen } \\
1\end{array}$} & 0,41 & Tinggi & 2 & 7,14 \\
\cline { 3 - 5 } & (sedang) & Sedang & 20 & 71,43 \\
\cline { 3 - 5 } & Jumlah & Rendah & 6 & 21,43 \\
\hline \multirow{2}{*}{$\begin{array}{c}\text { Eksperimen } \\
2\end{array}$} & 0,22 & & 28 & 100 \\
\cline { 3 - 5 } & (rendah) & Tinggi & 0 & 0 \\
\cline { 3 - 5 } & Jumlah & Redang & 7 & 26,92 \\
\hline
\end{tabular}

Data pada kelas eksperimen 1 dan eksperimen 2 menunjukkan adanya peningkatan hasil belajar pada kedua kelas mengalami peningkatan. Peningkatan hasil belajar ini dilakukan dengan menghitung nilai $\mathrm{N}$-Gain dari hasil pretest dan posttest. Pada kelas 
eksperimen 1 terjadi peningkatan hasil belajar dengan rata-rata $N$-Gain sebesar 0,41. Nilai tersebut termasuk ke dalam kategori sedang. Sedangkan pada kelas eksperimen 2 terjadi peningkatan hasil belajar dengan rata-rata $N$-Gain sebesar 0,22 . Nilai tersebut termasuk ke dalam kategori rendah.

Pada pengujian hipotesis penelitian ini menggunakan U-Test Mann Whitney. Berdasarkan hasil pengujian statistik didapat nilai $p$-value $=0,001$ pada taraf signifikansi $(\alpha)=0,025$. Disimpulkan bahwa $\mathrm{H}_{0}$ ditolak karena $p$-value $<\alpha(0,001<0,025)$. Pada penelitian ini $\mathrm{H}_{0}$ ditolak, yang mempunyai arti bahwa terdapat perbedaan peningkatan hasil belajar siswa yang signifikan antara kelompok yang menggunakan multimedia presentasi $(\bar{x} N$-Gain $=0,41)$ dengan multimedia interaktif $(\bar{x} N$-Gain $=0,22)$.

\section{PEMBAHASAN}

Berdasarkan hasil perhitungan dan analisis data yang telah dilakukan, menunjukkan bahwa terdapat perbedaan peningkatan hasil belajar siswa pada materi katup pneumatik yang diberikan pada pembelajaran dengan menggunakan multimedia presentasi dan multimedia interaktif. Pengaruh tersebut ditunjukkan dari gambaran hasil belajar dan gambaran peningkatan hasil belajar kedua kelas tersebut serta perbedaan peningkatan hasil belajar kedua kelas tersebut.

Data hasil belajar materi katup pneumatik, diperoleh nilai pretest dan posttest siswa sesuai dengan penilaian Kurikulum 2013. Distribusi predikat hasil belajar siswa pada kelas eksperimen 1. Deskripsi data hasil belajar materi katup pneumatik, diperoleh nilai pretest dan posttest siswa sesuai dengan penilaian Kurikulum 2013. Distribusi predikat hasil belajar siswa pada kelas eksperimen 2. Pada peningkatan hasil belajar yang diinterpretasikan dengan menggunakan nilai $\mathrm{N}$-Gain didapat distribusi kriteria $\mathrm{N}$-Gain pada kelas eksperimen 1. Pada kelas eksperimen 1 yang menggunakan multimedia presentasi pada pembelajaran materi katup pneumatik ini diperoleh peningkatan hasil belajar sesuai nilai $N$-Gain. Didapat siswa yang memperoleh peningkatan hasil belajar $(N$ Gain) dengan kategori rendah dengan frekuensi 21,43\%, sedang 71,43\% dan tinggi 7,14\%. Rata-rata peningkatan hasil belajar dengan nilai $\mathrm{N}$-Gain adalah 0,42 berada pada kategori sedang.

Penggunaan multimedia presentasi merupakan salah satu penyampaian materi pembelajaran dengan menggunakan perpaduan beberapa media. Pada penerapan pembelajaran materi katup pneumatik dengan menggunakan multimedia presentasi ini dapat meningkatkan hasil belajar (Kustandi dan Sutjipto, 2013). Hal tersebut sama dengan 
pendapat para ahli bahwa, multimedia dapat meningkatkan pemahaman siswa. Dengan demikian, dapat disimpulkan bahwa penggunaan multimedia presentasi dalam pembelajaran tentang katup pneumatik cukup efektif dilakukan. Pada peningkatan hasil belajar yang diinterpretasikan dengan menggunakan nilai $N$-Gain didapat distribusi kriteria $N$-Gain pada kelas eksperimen 2.

Pada kelas eksperimen 2 yang menggunakan multimedia interaktif pada pembelajaran materi katup pneumatik ini diperoleh peningkatan hasil belajar sesuai nilai $N$-Gain. Didapat siswa yang memperoleh peningkatan hasil belajar (N-Gain) dengan kategori rendah dengan frekuensi $73,08 \%$, sedang 26,92\% dan tinggi 0\%. Rata-rata peningkatan hasil belajar dengan nilai $N$-Gain adalah 0,22 berada pada kategori rendah.

Hasil belajar yang diperoleh siswa dipengaruhi oleh faktor intern dan ekstern. Pada pola pembelajaran dengan menggunakan multimedia interaktif hasil belajar yang diperoleh siswa dominan dipengaruhi oleh faktor intern. Karena pada pola pembelajaran ini, siswa melakukan pembelajaran multimedia interaktif, dimana setiap siswa difasilitasi dengan komputer untuk melakukan pembelajaran individu. Pembelajaran dengan menggunakan multimedia interaktif ini diperoleh peningkatan hasil belajar dengan presentase 26,92\% kategori sedang dan 73,08\% kategori rendah.

Penerapan multimedia dengan pola pembelajaran interaktif dapat meningkatkan hasil belajar siswa pada materi katup pneumatik. Pembelajaran berbantuan multimedia interaktif dianggap efektif jika $75 \%$ atau lebih dari siswa memperoleh peningkatan (gain) hasil pembelajaran minimal berkategori sedang (Hidayah \& Hasbullah, 2014). Dengan demikian, penggunaan multimedia interaktif dalam pembelajaran katup pneumatik ini kurang efektif dilakukan. Berdasarkan gambaran peningkatan hasil belajar siswa pada kedua kelas didapat bahwa kelas eksperimen 1 lebih baik daripada kelas eksperimen 2. Hal ini, ditunjukkan pada rata-rata peningkatan hasil belajar dua kelompok.

Berdasarkan analisis data pada pengujian hipotesis, didapat bahwa terdapat peningkatan hasil belajar antara kelompok yang menggunakan multimedia presentasi dan multimedia interaktif pada materi katup pneumatik. Perbedaan pada kedua pola pembelajaran ini ditunjukkan pada nilai rata-rata peningkatan hasil belajar dan nilai ratarata ranking pada pengujian hipotesis. Kedua hal tersebut, pola pembelajaran yang menggunakan multimedia presentasi memberikan pengaruh lebih baik dibandingkan multimedia interaktif.

Peningkatan hasil belajar siswa di kelompok kontrol (menggunakan gambar dan menerapkan metode pembelajaran klasik) memperoleh nilai rata-rata $N$-Gain 0,62 pada 
kategori sedang. Sedangkan, peningkatan hasil belajar di kelompok eksperimen (menggunakan animasi dan menerapkan metode pembelajaran semi individu) memperoleh nilai rata-rata $N$-Gain 0.35 pada kategori sedang (Purnawan, 2012). Multimedia yang diterapkan dalam kedua pola pembelajaran ini sesuai dengan salah satu tuntutan Kurikulum 2013 yang tertuang pada Permendikbud Nomor 70 Tahun 2013 yaitu pola pembelajaran yang berpusat pada peserta didik dan pola pembelajaran berbasis multimedia. Pola-pola pembelajaran tersebut diterapkan dalam pembelajaran dengan menggunakan multimedia presentasi dan multimedia interaktif. Pembelajaran berbasis multimedia tentang materi tentang katup pneumatik disarankan menggunakan multimedia presentasi dalam proses pembelajarannya. Kriteria cukup efektif pada peningkatan hasil belajar dibandingkan dengan menggunakan multimedia interaktif yang mempunyai kriteria kurang efektif terhadap peningkatan hasil belajar siswa.

\section{KESIMPULAN}

Penelitian ini disimpulkan bahwa terdapat peningkatan hasil belajar siswa antara kelompok yang menggunakan multimedia interaktif dan multimedia presentasi pada materi katup pneumatik. Rata-rata peningkatan hasil belajar siswa yang menggunakan multimedia presentasi berkategori sedang. Rata-rata peningkatan hasil belajar siswa yang menggunakan multimedia interaktif berkategori rendah. Ada perbedaan peningkatan hasil belajar siswa antara kelompok yang menggunakan multimedia presentasi dan multimedia interaktif. Nilai rata-rata $N$-Gain siswa yang menggunakan multimedia presentasi lebih baik daripada yang menggunakan multimedia interaktif. Penggunaan multimedia presentasi pada penelitian ini berpengaruh lebih baik pada peningkatan hasil belajar siswa dibandingkan penggunaan multimedia interaktif pada materi katup pneumatik.

\section{DAFTAR PUSTAKA}

Croser, P. and Ebel, F. (2002). Pneumatics: basic level. Denkendorf: Festo Didactic.

Direktorat Jenderal Pembinaan SMK. (2014). Aircraft hydraulic and pneumatic systems. Jakarta: Kemendikbud.

Hidayah, N. \& Hasbullah. (2014). Upaya peningkatan pemahaman siswa terhadap prinsip kerja pneumatik berbantuan perangkat lunak multimedia. Jurnal Pendidikan Teknologi Kejuruan: INVOTEC, 10 (1), p. 47-56.

Kusantati, H. (2014). Evaluasi multimedia ineraktif berbasis animasi pada pembelajaran teknologi desain busana. Jurnal Pendidikan Teknologi Kejuruan: INVOTEC, 10 (1), p. 35-46. 
Kustandi, C. \& Sutjipto, B. (2013). Media pembelajaran manual dan digital. Bogor: Ghalia Indonesia.

Munadi, Y. (2012). Media Pembelajaran Sebuah Pendekatan Baru. Jakarta: Gaung Persada Press.

Purnawan. (2006). Desain model komponen pneumatik untuk media pembelajaran mekanisme komponen pneumatik. Jurnal Pendidikan Teknologi Kejuruan: INVOTEC, 3(9), p. 116-124.

Purnawan. (2012). The implementation of animation as a mechanism of pneumatics component learning media. Proceedings of the $2^{\text {nd }}$ UPI International Conference on Technical and Vocational Education and Training (hlm. 202-207). Bandung: Faculty of Technology and Vocational Education Indonesia University of Education.

Rohani, A. (2004). Pengelolaan Pengajaran. Jakarta: Rineka Cipta. 